\title{
Alterations in the Serum Lipid Profile in Patients with Oral Cancer, Oral Precancerous Lesions/Conditions associated with the Habit of Tobacco Consumption
}

\author{
${ }^{1}$ Shilpa Dua, ${ }^{2}$ Sonal Vahanwala, ${ }^{3}$ Sandeep Pagare \\ ${ }^{1}$ Lecturer, Department of Oral Medicine and Radiology, ITS Dental College, Hospital \& Research Center, Greater Noida, UP, India \\ ${ }^{2}$ Professor, Department of Oral Medicine and Radiology, Dr DY Patil Dental College and Hospital, Mumbai, Maharashtra, India \\ ${ }^{3}$ Professor and Head, Department of Oral Medicine and Radiology, Dr DY Patil Dental College and Hospital, Mumbai, Maharashtra, India
}

Correspondence: Shilpa Dua, Lecturer, Department of Oral Medicine and Radiology, ITS Dental College, Hospital and Research Center, Greater Noida, Uttar Pradesh, India, e-mail: sukhjinderkhosa@ rediffmail.com

\begin{abstract}
The changes in lipid profile have long been associated with cancer because lipids play a key role in maintenance of cell integrity. Lipids are the major cell membrane components essential for various biological functions including cell growth and division of normal and malignant tissues. Lower blood lipids have been associated with the etiology of breast and colorectal cancer, and relation has also been reported between low cholesterol and increased risk of cancer occurrence and mortality.

The present study was designed to evaluate the serum lipid profile in patients with oral precancerous lesion/condition and squamous cell carcinoma to see whether there are any alterations in the lipid levels during the pathogenesis of these lesions and also to evaluate significance of lipid profile as biochemical marker, if any.
\end{abstract}

Keywords: Serum triglyceride, Serum cholesterol, Serum lipid, Oral precancerous lesions.

\section{INTRODUCTION}

"The more you learn,

M ore you come to know

....... how little you know"

This is so true when one tries to unveil the age-old disease of cancer.

A mong the prevalence of most debilitating and devastating disease in India and other A sian countries, oral cancer ranks the sixth most common cancer in the world and has particularly high incidence in Southeast A sian countries, as stated by J ohnson (1991); Parkin et al (1997). 1,2 Globally, oral cancer is third most common cancer in males, while in females it ranks fourth. ${ }^{3}$

L ipids are the major cell membrane components essential for various biological functions, including cell growth and division of normal and malignant tissues. It is believed that tobacco carcinogens induce generation of free radicals and reactive species, which are responsible for high rate of oxidation/peroxidation of polyunsaturated fatty acids. These peroxidation further releases peroxide radicals which affect essential constituents of the cell membrane and might be involved in carcinogenesis or tumorogenesis, ${ }^{4}$ due to which there is greater utilization of lipids including total cholesterol, lipoproteins and triglycerides for new membrane synthesis. Cells fulfill these requirements either from circulation, by synthesis through metabolism or from degradation of major lipoprotein fractions like high-density lipoprotein cholesterol, low-density lipoprotein cholesterol and very low-density lipoprotein cholesterol. ${ }^{4}$

\section{AIMS AND OBJECTIVES}

- To evaluate serum lipid profile in patients with oral cancer, oral precancerous lesions/conditions associated with the habit of tobacco consumption in any form and its comparison with the lipid profile among control groups

- To evaluate serum lipid profile in patients having the habit of tobacco consumption in any form but without any lesions present and its comparison with the lipid profile among control groups

- To assess whether the levels of serum lipid profile alter during the pathogenesis of oral cancer and oral precancerous lesions or conditions

- To assess whether the levels of serum lipid profile al ter in individuals with the habit of tobacco in any form but without any lesions when compared with the controls

- To assess whether such altered levels of serum lipid, if any could be used as a biochemical marker for oral cancer and oral precancerous lesions/conditions. 


\section{MATERIALS AND METHODOLOGY}

The study group consisted of 60 individuals and the control group consisted of 30 individuals.

\section{Study Group}

\begin{tabular}{|c|c|}
\hline Inclusion criteria & Exclusion criteria \\
\hline $\begin{array}{l}\text { Individuals having } \\
\text { habit of tobacco } \\
\text { (smoking, chewing } \\
\text { or snuff) }\end{array}$ & $\begin{array}{l}\text { Individuals suffering from } \\
\text { diseases that can alter the lipid } \\
\text { profile (diabetes mellitus, } \\
\text { uremia, nephritic syndrome, } \\
\text { hypothyroidism, hyperthyroidism } \\
\text { and acromegaly) }\end{array}$ \\
\hline \multirow{2}{*}{$\begin{array}{l}\text { Individuals having } \\
\text { clinically and } \\
\text { histopathologically } \\
\text { confirmed oral } \\
\text { leukoplakia, } \\
\text { oral submucous fibrosis } \\
\text { and oral squamous } \\
\text { cell carcinoma }\end{array}$} & $\begin{array}{l}\text { Individuals on lipid lowering } \\
\text { drugs }\end{array}$ \\
\hline & $\begin{array}{l}\text { Women on oral contraceptives. } \\
\text { Individuals not fit for biopsy or } \\
\text { failing to give their consent }\end{array}$ \\
\hline
\end{tabular}

Study group consisted:

Habit of tobacco with oral leukoplakia, oral submucous fibrosis or oral squamous cell carcinoma $\rightarrow 30$ of maxilla/mandible $\mathrm{H}$ abit of tobacco consumption but $\rightarrow 30$ without any lesions

30 individuals $\rightarrow$ control group $\rightarrow$ without habit of tobacco and with good systemic health

- Individuals of the study group were clinically examined for oral leukoplakia, oral submucous fibrosis and oral squamous cell carcinoma of maxilla/ mandible

- The findings were recorded on a custom-made case history proforma

- The study group having oral leukoplakia and oral submucous fibrosis were selected based on the clinical criteria explained by Southam ${ }^{5}$ and Daftary D K ${ }^{6}$ respectively. Carcinoma patients were selected using clinical criteria explained by Neville, Damn, Allen et $\mathrm{al}^{7}$

- For serum lipid profile analysis, minimum 12 hours fasting blood samples were obtained from each individual of the study group as well as control group

- This analysis was carried out at the Pathology Department of Dr DY Patil M edical H ospital, N erul, Navi M umbai, using fully automated biochemistry analyzer machine- 'Dade B ehring'.

\section{RESULTS}

For the convenience of tabulation, the study sample was divided as follows:

Group I Patients with oral precancerous Iesions/ conditions and oral squamous cell carcinoma, associated with the habit of tobacco in any form (study group).

Group II Patients with the habit of tobacco in any form but without any lesions (study group).

Group III Patients without the habit of tobacco and without lesions.

\section{RESULTS INFERENCE}

\section{Gender Distribution}

\begin{tabular}{llll}
\hline Srno & Groups & Males & F emales \\
\hline 1. & I & $70 \%$ & $30 \%$ \\
2. & II & $73.33 \%$ & $26.7 \%$ \\
3. & III & $56.67 \%$ & $43.33 \%$ \\
\hline
\end{tabular}

In patients with oral cancer, habit of gutka chewing was more prevalent ( $35 \%$ ) followed by beedi smoking ( 25\%) and chewing tobacco with lime ( $25 \%)$. Habit of cigarette smoking was seen exclusively in this group as compared with patients with oral precancerous lesion/condition.

In patients with oral precancerous lesion/condition, habit of gutka chewing and chewing of tobacco with arecanut $(\sim 26 \%)$ was seen to be more preval ent (Fig. 1).

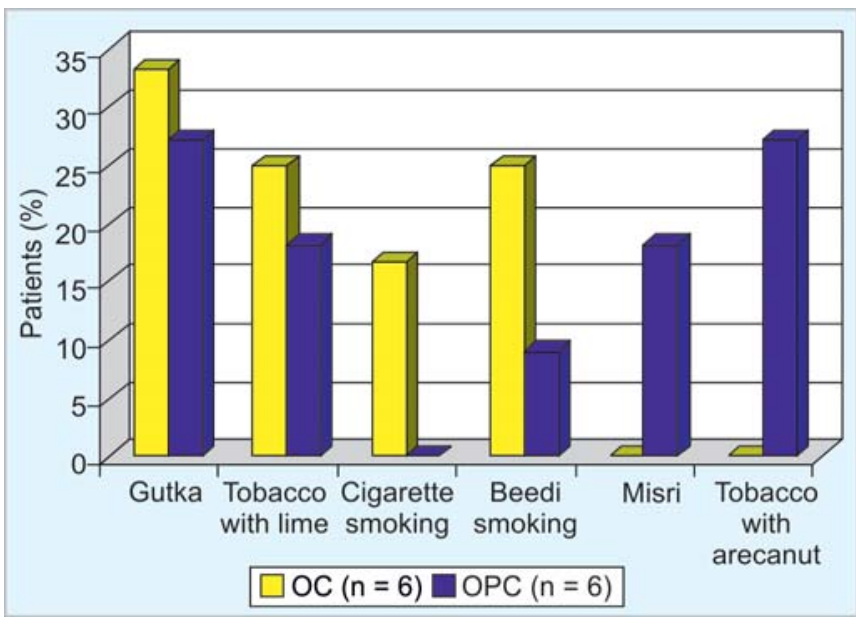

Fig. 1: The prevalence (\%) of patients with different tobacco chewing habits

Mean Values of Five Parameters of Serum Lipid for Three Groups

\begin{tabular}{llllll}
\hline Groups & $\begin{array}{l}\text { Serum } \\
\text { triglyceride }\end{array}$ & $\begin{array}{l}\text { Serum } \\
\text { cholesterol }\end{array}$ & HDLC & LDLC & VLDLC \\
\hline Group I & 109 & 166.2 & 41.27 & 98.9 & 21 \\
Group II & 134 & 162 & 43.57 & 91.63 & 26 \\
Group III & 118.1 & 162.4 & 34.7 & 104.3 & 23 \\
\hline
\end{tabular}


- The levels of serum cholesterol, high-density lipoprotein cholesterol (HDLC) and low-density lipoprotein cholesterol (LDLC) were statistically significantly lower in patients with oral cancer $(\mathrm{OC})$ when compared with the levels of patients with oral precancerous lesion/ condition (OPC)

- The levels of serum triglyceride, serum cholesterol, HDLC and very low density lipoprotein cholesterol (VLDLC) were statistically significantly lower in patients with OC when compared with the levels of patients without the habit of tobacco consumption without any lesions (group III)

- The level of HDLC was statistically significantly higher in patients with oral precancerous lesion/condition when compared with the levels of patients without the habit of tobacco consumption without any lesions (group III)

- The level of HDLC in patients with the habit of tobacco consumption in any form but without lesions (group II) was statistically significantly higher when compared with the controls (group III).

\section{DISCUSSION}

It is estimated that about 9 million new cases of cancer are diagnosed every year and over 4.5 million people die from cancer each year. ${ }^{8}$ Cancer of oral cavity is one of the commonest cancers among males ${ }^{9}$ and sixth most common cancer in the world. Phospholipids and cholesterol have been reported to undergo early and significant changes in certain types of malignant tumors. The process of carcinogenesis could be responsible for low levels of cholesterol in the proliferating tissues and in the blood compartments. ${ }^{10}$

In a study conducted by Fu-Chuan Chao et al, ${ }^{11}$ it was stated that hypolipidemia is a result of direct lipid lowering effect of tumor cells as these neoplastic cells directly utilize cholesterol for their own metabolism. The profound effect of hypolipidemia should be recognized and an early measure should be made to restore cholesterol levels to avoid conditions that may hasten morbidity and mortal ity in cancer patients.

In another study conducted by $\mathrm{M}$ in-A $\mathrm{h}$ Choi et al, ${ }^{12}$ it was suggested that hypocholesterolemia was secondary to decreased levels of serum antioxidative vitamins. Decrease in the level of antioxidative vitamins in serum results in increased number of free radicals which causes increased lipid peroxidation.

Schatzin et al ${ }^{13}$ and Choyu et al ${ }^{14}$ have observed an inverse trend between lower serum cholesterol level and head, neck as well as esophageal cancer.

The results are strengthen by the present study which also shows lower serum levels of triglycerides, total cholesterol, HDLC and VLDLC in patients with oral cancer when compared with controls.

A ccording to Nydegger et al, ${ }^{10}$ the observed decrease in lipoprotein and cholesterol levels was possibly due to:

- Increased catabolism of $\alpha_{1}$-lipoprotein and cholesterol
- Decreased synthesis of $\alpha_{1}$-lipoprotein and cholesterol by liver as the synthesis is affected by tumor metabolites

- Antibodies to lipoproteins which could lead to accelerated immune elimination of antigen-antibody complex.

In neoplastic tissue, an increased low-density lipoprotein receptor activity in tumor cells may produce hypocholesterolemia. ${ }^{15}$

$\mathrm{S}$ D esai et $\mathrm{al}^{16}$ proposed that free cholesterol within the tumor cells, is preferentially channeled into storage as cholesterol esters rather than being released from the cells to circulating HDL. This happens irrespective of whether the free cholesterol is arising from synthesis or uptake in the tumor cells. This mechanism explains the decreased levels of HDLC in cancer patients.

In accordance with the above-mentioned studies, the present study shows declined serum levels of total cholesterol, HDLC, V LDLC and triglyceride in patients with oral cancer as compared with that of controls. The results of the study add to the evidence of an inverse relationship between lower serum lipid profile and oral cancer. The levels of serum cholesterol, HDLC and LDLC were declined in patients with oral cancer when compared with the levels in patients with oral precancerous lesions/conditions. Thus, it can be stated that the lower serum lipid status may be a useful indicator, i.e. biochemical marker for initial changes occurring in neoplastic cells.

\section{CONCLUSIONS}

The study concludes that:

- The habit of tobacco consumption was more preval ent among male patients than female patients in both the groups, i.e. I and II, with habit of gutka chewing and chewing of tobacco with arecanut ( $26 \%)$ being more prevalent

- The levels of serum cholesterol, HDLC and LDLC were statistically significantly lower in patients with $O C$ when compared with the levels of patients with OPC

- The levels of serum triglyceride, serum cholesterol, HDLC and V LDLC were statistically significantly lower in patients with $O C$ when compared with the levels of patients without the habit of tobacco consumption without any lesions (group III)

- Altered lipid profiles in the form of elevated HDLC levels were observed in patients with the habit of tobacco in any form but without any lesions when compared with the controls thereby; suggesting that tobacco consumption in any form has an adverse effect on lipid profile

- The serum lipid levels were statistically significantly lowered in patients with oral cancer when compared with the normal control group. Hypolipidemia was found to be associated with oral cancer patients when compared with normal control group. Thus, hypolipidemia can be considered as a one of the biochemical marker in early detection of cancer. 


\section{REFERENCES}

1. Johnson NW. A global view of epidemiology of oral cancer. In risk makers for oral disease, J ohnson NW , (ed), University Press, Cambridge 1991;2:2-27.

2. Parkin W. Carcinoma incidence in five continents. IA RC, Lyon 1997; 7:143.

3. Parkin W. Estimates of the world wide incidence of eighteenx major cancers in 1985. Int J of Can 1993;54:594-606.

4. Patel PS, Shah M H, Raval GN, et al. A lterations in plasma lipid profile pattern in head and neck cancer and oral precancerous conditions. Ind J Cancer 2004;41(1):25-31.

5. Southham JC, Soames JS. Textbook of oral pathology (2nd edn). Oxford U niversity Press No 138.

6. Dafftary DK, M urti PR, M ehta FS, et al. Oral precancerous lesions and conditions of tropical interest. In: Prabhu SR, Wilson DF (Eds). Oral diseases in tropics, Delhi 1993;402-24.

7. Neville, Damn, Allen, et al. Textbook of oral and maxillofacial pathology. (2nd edn) pp. 359.

8. B urket $L W, V$ ernon JB. Burket's oral medicine diagnosis and treatment (9th edn). JB L ipppincot Co: 1994.

9. Iype EM , Pandey M, M athew A , etal. O ral cancer among patients under the age of 35 years. 2001;47(3):171-76.
10. Nydegger UE, Butler RE. Serum lipoprotein levels in patients with cancer. Can Res 1972;32:1756-60.

11. Chao Fu-Chuan, Efron Bradley, Wolf Paul. The possible prognostic usefulness of assessing serum proteins and cholesterol in malignancy. Can Res 1975;35:1223-29.

12. Choi M in-ah, Kim Byung-Sick, Rina YU. Serum antioxidative levels and lipid peroxidation in gastric carcinoma patients. Cancer Letters 1999;136:89-93.

13. Arthur Schatzkin, Robert N Hoover, Philip R Taylor, et al. Site specific analysis of total serum cholesterol and incident of cancer in the national health and nutrition examination survey I epidemiologic follow-up study. Can Res 1988;48:452-58.

14. Chyou Po-huang, Abraham MY Nomura, Grant N Stemmermannn, et al. Prospective study of serum cholesterol and site-specific cancers. J Clin Epidemiol 1992;45:287-92.

15. Vitols SG, Bjorknolm M, Gösta Gahrton, et al. Hypocholesterolemia in malignancy due to elevated low-density lipoprotein receptor activity in tumor cells. Evidencefrom studies in patients with Leukemia. Lancet 1985;2:1150-54.

16. Desai $S, B$ atetta $B, P$ ani $P$, et al. A ltered pattern of lipid metabolism in patients with lung cancer. Oncology 1992;49: 436-41. 